New product approvals

Product Companies Details

\begin{tabular}{ll}
\hline $\begin{array}{l}\text { Caelyx } \\
\text { (pegylated liposomal }\end{array}$ & $\begin{array}{l}\text { Schering Canada } \\
\text { (Pointe-Claire, PQ) }\end{array}$ \\
$\begin{array}{l}\text { doxorubicin } \\
\text { hydrochloride) }\end{array}$ &
\end{tabular}

Caelyx was approved on January 30 in Canada as a second-line defense against advanced ovarian cancer in women, which kills 1,500 Canadian women a year. Caelyx, which will be marketed by Schering is already approved for late-stage ovarian cancer in Europe, and has received orphan status in the United States, where it is marketed as Doxil by Alza (Mountain View, CA). The product is also approved for AIDS-related Kaposi's sarcoma in Canada, Europe, and the United States.
On February 5, AHP received marketing approval for Prevenar in Europe for infants and children up to two years old to prevent invasive pneumococcal disease-which includes pneumonia, bacteremia (bacterial infection of the blood), sepsis, and meningitis-which kills over one million children under the age of two worldwide. Prevenar was approved in the United States in February 2000, and has no competitors.

The European Medicines Evaluation Agency approved high-dose Rebif as a first-line therapy for treatment of relapsing-remitting multiple sclerosis (MS) in Europe, where it affects 450,000 people. On February 5, Rebif became the only interferon- $\beta$ product granted full approval by the European Commission; all others require annual reassessment. Rebif delays progression of MS and reduces the number and severity of relapses.

\section{Celltech clinches product deal with Pharmacia}

In what analysts are calling the most lucrative deal yet for a phase II product, Pharmacia (Peapack, NJ) announced on March 5 that it will pay Celltech (Slough, UK) around $\$ 280$ million in up-front and milestone payments for global co-development and co-promotion rights for rheumatoid arthritis treatment CDP 870, in addition to a share of profits rather than royalties. Industry insiders say that a bidding war among several pharmaceutical giants helped raise the stakes, but Wilson says CDP 870 could have significant advantages over Immunex's (Seattle, WA) rival antiTNF $\alpha$ antibody Enbrel, which saw sales of over $\$ 650$ million in 2000: CDP 870 acts through a target similar to that of twicedaily-dosage Enbrel, but its much longer half-life could reduce dosage to once a month; furthermore, CDP 870 is a partial antibody that is significantly cheaper to produce. Pharmacia already has a strong presence in the arthritis market with the blockbuster anti-inflammatory drug Celebrex. Celltech's share rose $82 \mathrm{p}$ to $£ 14.17$ (\$20.83) following the news. $L F$

\section{Biotech bandit busted}

A US federal court has sentenced California biotech executive Michael Craig Dickman to nine years in jail for a series of bank robberies in 1999 that were designed to keep afloat his struggling bioinformatics firm. In 1998, the so-called "gap-toothed bandit" founded Socratix Systems (San Diego, CA), which struggled and went out of business in January 2000. According to his courtappointed attorney Stephen Hoffman,
Dickman was previously diagnosed with bipolar disorder, thrice divorced, and faced personal debts of $\$ 1$ million and corporate debts of more than $\$ 4$ million tied to the failure of Socratix. In August 2000, Dickman pled guilty to robbing six banks in San Diego from October to December 1999, and federal law enforcement authorities connected him with six additional robberies that occurred around the same time. Hoffman said Dickman's mental health problems contributed to his behavior: "He was feeling pressured to stay afloat. That in conjunction with bipolar disorder made him do desperate things." Dickman also founded ChromaXome (San Diego, CA) in 1993, which was purchased by Trega Biosciences (San Diego, CA) in 1995 and then by TerraGen Diversity (Vancouver, BC) in March 1999.

EN

\section{EU prioritizes genomics}

On February 21, the European Union published its grant-giving Framework VI program for 2003-2006, earmarking $€ 2$ billion (\$1.8 billion) for Genomics and Health Biotechnology, a new priority for the EU. As an incentive to develop the private sector in Europe, $15 \%$ of these funds are allotted to small and medium enterprises-up from 10\% in Framework V-with the rest destined for the public sector. "Genomics has emerged with a much higher political priority [than in the current programme]," comments Mark Cantley from the EU Directorate General Research. "The [international] nature of genomics makes it suitable for community funding," he adds. The new program aims to develop collaborative research networks across Europe to eliminate redundant research, and encourages researchers to travel to labs in different countries to strengthen these networks. Biotechnology researchers could also receive Framework VI funding if their activities fall under alternative categories: food safety (€600 million available), nano-technologies ( $€ 1.3$ billion), or sustainable development and global change (€1.7 billion).

\section{USDA, EPA remove StarLink corn from feed}

US regulatory officials recently took several steps to eliminate any future occurrences similar to Aventis CropScience's (Research Triangle Park, NC) StarLink corn debacle last year, when GM corn containing the insecticidal Cry9C protein approved for use in animal feed was discovered in peoples' food products (Nat. Biotechnol. 19, 11, 2001). In March, officials at the Environmental Protection Agency (Washington, DC) announced that GM crops will no longer be licensed for animal feed unless also approved for human consumption. In addition, agency officials invited public comments on a draft document describing how food processing can affect levels of the insecticidal protein in finished products: wet milling removes essentially all such protein from finished foods (such as in oils), whereas dry-milling procedures (used to make cornmeal) do not. Also in March, the United States Department of Agriculture (USDA; Washington, DC) agreed to purchase seeds that inadvertently contain genes encoding the Cry9C protein. Although industry estimates say less than $1 \%$ of such corn seed is currently in the system, the USDA expects this seed purchase program will cost between $\$ 15$ million and $\$ 20$ million. JF 